\title{
Science Process Skill in Science Program Higher Education
}

\author{
Maison, Darmaji, Aatalini, Dwi Agus Kurniawan*, Haryanto, Wawan Kurniawan, Ai Suryani, \\ Artha Lumbantoruan, Utari Prisma Dewi
}

Faculty of Teaching and Education, Universitas Jambi, Indonesia

Received November 20, 2019; Revised January 6, 2020; Accepted January 13, 2020

Copyright $\bigcirc 2020$ by authors, all rights reserved. Authors agree that this article remains permanently open access under the terms of the Creative Commons Attribution License 4.0 International License

\begin{abstract}
This study aims to determine differences in mastery of process skills science student physics and chemistry education study programs both in the experimental class and control class. The experimental class uses a science process skill-based guide with the inquiry model, while the control class uses conventional guidance. This research is a quantitative type of experimental research with a group comparison design static. The research sample was 201 students. Observations are made by using the observation sheet instrument. The results of this study indicate that there are differences in the mastery of science process skills between students using an inquiry model practicum guide and students who use conventional practicum manuals in each study program. Based on the results of hypothesis testing using an independent sample t-test at a significance level of $5 \%$, a significance value of 0.000 was obtained in the study program physics and chemistry education. Where based on statistical parameters used it can be concluded that the mastery of science process skills in the experimental class is better than the mastery of science process skills in the control class.
\end{abstract}

Keywords Physics Education, SPS, Chemistry Education

\section{Introduction}

Physics is a science that is in contact with everyday life and with scientific formulas and concepts. The physics education study program is one of the study programs which is available in a faculty of teacher and education which has aim to produce skilled graduates in various aspects of competence such as knowledge, understanding, and skills [1] [2]. According to [3], "There are two reasons why we must study physics, first, one of the most basic sciences is physics, secondly all the sciences of technology and also for engineering is the basis of learning". According to [4] [5] for problem-solving can be implemented by guiding students to apply the existing knowledge in themselves. Transferable skills can be developed through science learning processes in classrooms or practicum in laboratories[1]. Basic physics is one of the compulsory courses found in physics education study programs and chemical education study programs at the University of Jambi in the odd semester with a weight of 4 credits ( 3 credits face to face and 1 credit practicum).

Practicum is learning to prove the principles and concepts of physics through experimental activities in the laboratory [6]. Basic Physics Practicum aims to assist students in solving problems of natural phenomena and train students' science process skills (SPS). [7] Practicum as a laboratory activity that plays a role in supporting the success of the science learning process. Practicum activities are one of the methods used to clarify the material that has been learned. Practicum is teaching that aims to make students prove what is obtained in theory [8]. In practical activities, students can observe, plan experiments, interpret data, conduct experiments, and communicate data on the results of experiments. The activity is an activity that can improve students' science process skills.

Science process skills are the ability to process scientific thought and the ability to process actions to develop an understanding of scientific concepts [9]. According to [10] students' scientific process skills are important skills to be developed in education. Process skills are also considered a scientific method used to train students' steps in finding things through experimental activities [11] [12]. Science process skills are very important for every student as a provision to use scientific methods in developing science and are expected to acquire new knowledge or develop existing knowledge [12]. 
Students who have science process skills can practice understanding the concepts they have acquired in learning activities which have two categories, basic science process skills, and integration science process skills [13].

According to [14], the skills of basic science process skills include observing, communicating, classifying, inferring, and predicting. While integrated science process skills include identifying variables, constructing a table of data, constructing a graph, describing relationships between variables, accounting and processing your data, analyzing investigations, constructing hypotheses, defining variables operationally, designing experiments, and experimenting. Basic science process skills are: observing, classifying, communicating, measuring, predicting, and inferring [15]. Observation is an activity to collect data about an object or event using all appropriate information or with an instrument to expand the senses [16]. Classification is the process of sorting, grouping, and organizing based on similarities and differences. Communicating is the skill of conveying and obtaining facts, concepts, principles, and knowledge in oral, written and picture form. Measuring is a number of terms and conditions as a quantitative term. Predicting is to anticipate the consequences of changing past experiences and previous observations. Make skills predictive including information observed to interpret, or make initial conclusions. Life Skill's basic science process is the basis for the development of integrated science process skills. So, students who have mastered basic science process skills well will easily master integration science process skills.

Integrated process skills include identifying variables, making data tables, making graphs, describing relationships between variables, obtaining and processing data, compiling hypotheses, determining operational variables, designing experiments, and conducting experiments [17]. Integrated science process skills are used when learning requires experimental activities [18]. Skills included in experimental design skills are skills in determining the tools and materials to be used in research. Experiments are interpreted as activities carried out to test hypotheses based on the results of the manipulation of independent variables on the dependent variable.

As a prospective professional educator, students have the task to guide, train and build one's knowledge [19] [20] [21]. Science process skills are needed by students as prospective teachers to have pedagogic competence which is expected to be a time of skills and expertise directly into the field [22]. The physics education study program has a goal to produce graduates who are skilled in various aspects of competence, especially skill competence [23]. Because science process skills emphasize the learning process, accreditation, creativity, values and also the attitude of a student who will later be applied in daily life, so science process skills have a relationship with the motivation of a student [24]. Guides used by students, especially in the Basic Physics practicum, are currently using conventional guides. To train students' science process skills, a guide book is needed based on aspects of the science process skills. Science process skills (SPS) based experiment guides help improve skills mastery scores on several indicators of basic science process skills and integrated science process skills [24]. Therefore, students need to read a guide book that contains experimental procedures that are in order and clear. Thus this study aims to determine the differences in the mastery of science process skills in the experimental class and control class students who are given different guidebooks in each physics education study program and each chemistry education study program.

\section{Materials and Methods}

\subsection{Research Participants}

This research was conducted at the University of Jambi Physics Education Study Program, Indonesia. The sampling technique uses a total sampling technique. The total sampling technique is a technique that allows researchers to take samples from the entire population [25]. The total sampling technique is used to minimize generalization errors from the results of the study. The research sample was all students of physics education study programs and all students of chemical education study programs who contracted basic physics courses in odd semester of the academic year 2019/2020. The research sample consisted of 201 students, consisting of 108 students of physics education study programs, and 93 students of chemical education study programs

\subsection{Research Design}

This research is a quantitative study with the type of experiment using a static group comparison design. In the comparison group, design research participants were not randomly assigned to the two treatment groups, with a posttest and no pre-test [26].

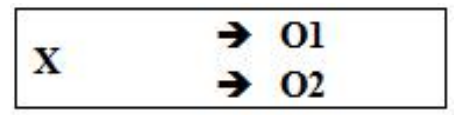

Figure 1. Statistical design of group comparison

Information:

$\mathrm{X}$ : Treatment

O1: Observation of the experimental group

O2: Observation of the control group

The research sample divided into two classes for each study program, namely: the experimental class and the 
control class. The experimental class and the control class are determined by giving a pre-test in the form of multiple-choice questions. The pretest used has been tested to determine its validity and reliability. Of the 50 multiple choice questions, 36 valid questions were obtained and Cronbach alpha was .924. The pre-test data were then analyzed using the normality test and homogeneity test. The analysis shows that the data are normally distributed (sig. $=.200$ at the $5 \%$ significance level) and homogeneous (sig. $=.948$ at the $5 \%$ significance level). These results indicate that the cognitive abilities of students in each class are the same, so there is no significant difference between students in the experimental class and the control class. After determining the students of the experimental class and the control class, they are then given a different guide for each class. Practicum guidance is given an experimental class using a model-based inquiry science process skills. While the control group was given conventional guidance.

\subsection{Data Collection}

Data collection techniques use observation and documentation. Observations were made when students conducted experiments. Observations were made by 20 observers using observation sheets. We can measure students' science process skills using observation sheets [27]. The observation sheets and rubrics used were adopted from the research conducted by [28]. To maintain the accuracy of observational data, observers are first explained the science process skills. Besides, the observer was also given directions on how to fill in the observation sheet based on the observation sheet rubric.

In this study, researchers wanted to see the difference science process skills of students based on indicators of basic science process skills (observation, prediction, communication) and integrated basic science process skills (planning experiments, analyze the experiment, conducting experiments, defining variables, create tables). This research is also complemented by documentation studies conducted to complete the observation data. With documentation studies, the results of observations will be more reliable. Documents to be analyzed in this study include preliminary reports, final reports, and photos during practical activities.

\subsection{Data Analysis}

In quantitative research where observational instrument products are number [29]. Data from observations were analyzed using descriptive statistics and inferential statistics. Descriptive statistics are used to describe the mastery of students' science process skills in the experimental class and the control class. The statistical parameters used include Mean, Mode, Standard deviation, range, Maximum, Minimum, and Quartile. Besides, for mastery of each indicator of science process skills will be presented in the frequency distribution tables and graphs. The mastery of science process skills in each indicator is divided into four categories, namely; very good, good, not good and very not good. the mastery category for each indicator is presented in table 1 below.

Table 1. Mastery Category Indicator SPS

\begin{tabular}{|c|c|c|}
\hline No & Interval & Category \\
\hline 1 & $1.00-1.75$ & Very not good \\
\hline 2 & $1.76-2.50$ & Not good \\
\hline 3 & $2.51-3.25$ & Good \\
\hline 4 & $3.26-4.00$ & Very good \\
\hline
\end{tabular}

Inferential statistics are used to answer the research hypothesis. Data generated by the statistical group comparison design can be analyzed by conducting tests. But if the scores deviate considerably from the normal distribution, it can be analyzed by nonparametric tests most likely to be the Mann-Whitney U-test [26]. Data analysis was performed using the SPSS v.24 application.

\subsection{Research Hypothesis}

Ho: There is no difference in the mastery of science process skills between students' experimental and control classes in each study program.

$$
\overline{x_{1}}=\overline{x_{2}}
$$

Ha: There are differences in the mastery of science process skills between the experimental class students and the control class in each study program.

$$
\overline{x_{1}} \neq \overline{x_{2}}
$$

\section{Results and Discussion}

Based on the statistical analysis test conducted with the help of SPSS v.24 application, the results of the analysis of science process skills in physics education study program students and chemistry education study program students are based on observations in the experimental and control classes as follows:

\subsection{Physics Education Study Program}

Table 2. Test results for normality of physics education study program

\begin{tabular}{|c|c|c|c|}
\hline \multirow{2}{*}{} & \multicolumn{3}{|c|}{ Kolmogorov-Smirnov } \\
\cline { 2 - 4 } & Statistic & df & Sig. \\
\hline Experiment & 0.096 & 41 & $.200^{*}$ \\
\hline Control & 0.078 & 41 & $.200^{*}$ \\
\hline
\end{tabular}

The normality test was carried out at a significance level of $5 \%$, obtained significance values from the experimental class and the control class .200 . Based on the significant value it can be concluded that the mastery 
of data science process skills in the experimental class and the control class are normally distributed. This is in accordance with the criteria if $\mathrm{sig}>0.05$, then the data is distributed normal [30].

Table 3. Test results for homogeneity of physics education study program

\begin{tabular}{|c|c|c|c|}
\hline Levene Statistic & df1 & df2 & Sig. \\
\hline 0.024 & 1 & 106 & 0.878 \\
\hline
\end{tabular}

The homogeneity test results at the $5 \%$ significance level obtained a significance value of 0.878 . Based on the significance of the results it can be concluded that the data mastery of SPS of the experimental group and control group students have the same variance. This corresponds to the criteria if the value is sig. $>0.05$, then the two data tested are homogeneous.

Table 4. T-test results for independent samples of physics education study programs

\begin{tabular}{|c|c|c|c|}
\hline Mastery of SPS & $\mathrm{t}$ & $\mathrm{df}$. & Sig. (2-tailed) \\
\hline $\begin{array}{c}\text { Equal variances } \\
\text { assumed }\end{array}$ & 12.534 & 106 & 0.000 \\
\hline $\begin{array}{c}\text { Equal variances not } \\
\text { assumed }\end{array}$ & 12.534 & 105.39 & 0.000 \\
\hline
\end{tabular}

Based on the results of the independent sample t-test at a significance level of $5 \%$, the significance value (the same variant) is 0.000 . Because of the significance value> 0.05 , it can be concluded that there are differences in the mastery of science process skills in the experimental class and the control class.

In general, the value of the statistical parameters in the experimental class is higher than in the control class. The average value of the experimental class (3.01) is greater than the average value of the control class (2.33). this is based on the experimental class quartile value greater than the control class quartile value. Based on these parameters, it can be concluded that the mastery of experimental class science process skills is better than mastery of control class science process skills.

Figure 2 shows that the average experimental class students from physics education study programs have mastered science process skills well. The indicator of creating a data table is the dominant indicator that is most mastered by students of the experimental class. While indicators the indicators identify variables into the dominant indicator that is least controlled by the experimental class students.

Table 5. The results of the analysis of statistical parameters of the physics education study program

\begin{tabular}{|c|c|c|c|c|c|c|c|c|c|}
\hline \multirow{2}{*}{ Class } & \multirow{2}{*}{ Mean } & \multirow{2}{*}{ Mode } & Std. Deviation & \multirow{2}{*}{ Range } & \multirow{2}{*}{ Min } & \multirow{2}{*}{ Max } & \multicolumn{3}{|c|}{ Quartile } \\
\cline { 6 - 11 } & & & & & & Q1 & Q2 & Q3 \\
\hline Experiment & 3.01 & 3 & 0.292443 & 1.4 & 2.16 & 3.56 & 2.87 & 3.01 & 3.22 \\
\hline Control & 2.33 & 2.42 & 0.271102 & 1.05 & 1.79 & 2.84 & 2.13 & 2.35 & 2.55 \\
\hline
\end{tabular}

Table 6. Distribution of mastery indicator science process skills in the experimental class physical education courses

\begin{tabular}{|c|c|c|c|c|}
\hline Basic SPS indicator & Very Not Good & No Good & Good & Very Good \\
\hline Observing & 0 & 3 & 24 & 27 \\
\hline Predicting & 2 & 2 & 14 & 36 \\
\hline Communicating & 2 & 15 & 28 & 9 \\
\hline Integrated SPS indicator & Very Not Good & No Good & Good & Very Good \\
\hline Planning an experiment & 2 & 4 & 24 & 26 \\
\hline Analyzing an experiment & 6 & 3 & 25 & 25 \\
\hline Experimenting & 1 & 4 & 17 & 26 \\
\hline Defining variables & 4 & 3 & 14 & 37 \\
\hline Creating data tables & 0 & & 25 \\
\hline
\end{tabular}




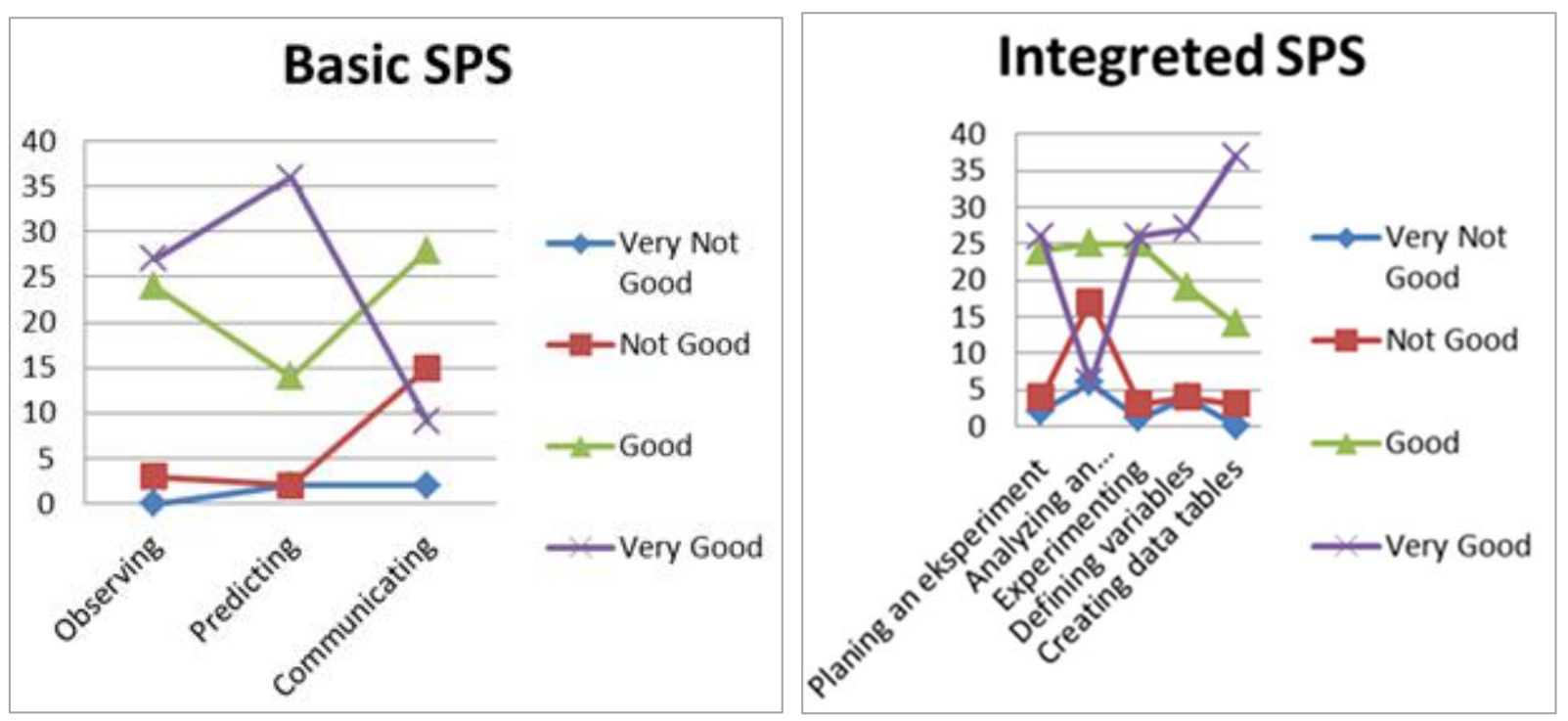

Figure 2. Distribution of SPS indicator mastery in the experimental class of physics education study programs

Table 7. Distribution of mastery of science process skills indicators for control classes of physics education study programs

\begin{tabular}{|c|c|c|c|c|}
\hline Basic SPS indicator & Very Not Good & No Good & Good & Very Good \\
\hline Observing & 0 & 16 & 35 & 3 \\
\hline Predicting & 5 & 13 & 17 & 19 \\
\hline Communicating & 17 & 6 & 25 & 6 \\
\hline Integrated SPS indicator & Very Not Good & No Good & Good & Very Good \\
\hline Planning an experiment & 4 & 23 & 24 & 3 \\
\hline Analyzing an experiment & 22 & 27 & 3 & 25 \\
\hline Experimenting & 1 & 4 & 19 & 27 \\
\hline Defining variables & 4 & 8 & 31 & 13 \\
\hline Creating data tables & 2 & & 25 \\
\hline
\end{tabular}
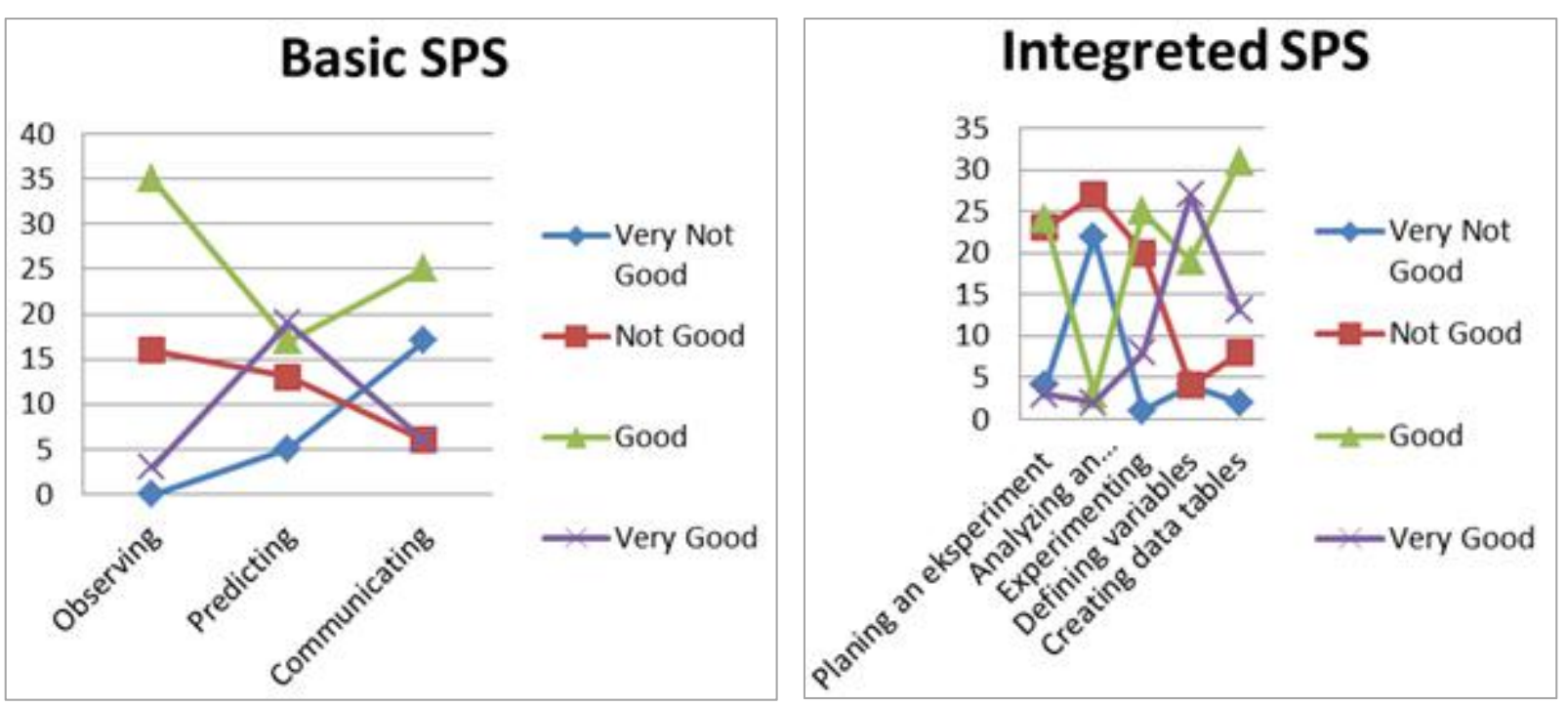

Figure 3. Distribution of mastery of SPS Indicators for control of physics education study programs 
Table 7 and Figure 3 show that the average mastery of science process skill indicators in the control class is categorized as not good. The indicator most mastered by students is the observation indicator. Indicators that are not controlled by the control class is an indicator of defining variables.

Table 6 and Figure 2 show that in general students in the experimental class mastered each indicator of the science process skills very highly well. The indicator most mastered by students in the experimental class is the indicator to make data tables. This can be seen from the interim report data and observation sheets. Students in the experimental class are very good at making data tables. Students create labels (column headings) that are appropriate for each column. $\theta_{1}, \theta_{2}, \alpha_{1}, \alpha_{2}, \alpha_{3}, w$ Students can create recurring data tables for each experiment. Besides, students can also make a graph based on data in the data table that has been created.

The high mastery of science process skills in making data tables because students have mastered basic science process skills well. Basic science process skills are a prerequisite for science process integration skills [31]. Skills in making data tables are one indicator of skills in the process of science integration. Integration science process skills are complex skills/combinations of some basic science process skills. Skills in making data tables are influenced by classification and observation skills. Because students have mastered classification and observation skills well, so students can easily master data table making skills.

Indicators of science process skills that most are not controlled by the students in the experimental class is a skill defining variables. Students are still confused in determining the independent variable, the dependent variable, and the control variable. This is because the practical guide has not directed students to identify the variables for each experiment. When conducting experiments, students are still in the learning and practicing stages, so there is a need for clear practicum guidelines [32]. Practicum guides only contain definitions of independent variables, dependent variables, and control variables without examples. This is based on students' temporary reports, most students can only identify the dependent variable.

Table 7 and Figure 3 shows the indicator most are not controlled by a control class is science process skills on indicators defining variables. Students in the control class are very unskilled in defining independent variables, dependent variables and control variables. This is because the lab guide used by students in the control class does not explain these three variables. so it makes sense that students in the class can't control master indicator defining variables correctly.

\subsection{Chemistry Education Study Program}

Table 8. Test results of the chemistry education study program normality

\begin{tabular}{|c|c|c|c|}
\hline \multirow{2}{*}{} & \multicolumn{3}{|c|}{ Kolmogorov-Smirnov ${ }^{\mathrm{a}}$} \\
\cline { 2 - 4 } & Statistic & $\mathrm{df}$ & Sig. \\
\hline Experiment & 0.083 & 41 & $.200^{*}$ \\
\hline Control & 0.113 & 41 & $.200^{*}$ \\
\hline
\end{tabular}

Normality test is done at a significance level of $5 \%$, the value of the significance of the experimental class and control class .200. Based on the significant value it can be concluded that the mastery of science process skills in the experimental class and normally distributed control class. This is in accordance with the criteria if sig $>0.05$, then the data are normally distributed [33].

Table 9. Test results for the homogeneity of chemistry education study programs

\begin{tabular}{|c|c|c|c|}
\hline Levene Statistic & df1 & df2 & Sig. \\
\hline 1.052 & 1 & 91 & 0.308 \\
\hline
\end{tabular}

Homogeneity test results at a significance level of $5 \%$ obtained a significance value of 0.308 . Based on the significant value it can be concluded that the mastery of science process skills from the experimental class and the control class have the same variant. This is in accordance with the criteria if the value is sig. $>0.05$, then the two data tested are homogeneous.

Table 10. Test results for independent samples of t-test chemistry education study programs

\begin{tabular}{|c|c|c|c|}
\hline Mastery of SPS & $\mathrm{t}$ & $\mathrm{df}$ & Sig. \\
\hline Equal variances assumed & 10.637 & 91 & 0.000 \\
\hline Equal variances not assumed & 10.657 & 88.794 & 0.000 \\
\hline
\end{tabular}

Test results by independent sample $t$-test at a significance level of $5 \%$ significance value (same variant) 0,000 . Due to the significant value of $>0.05$, it can be concluded that there are differences in the mastery of science process skills in the experimental class and the control class.

Table 11. The results of the analysis of the statistical parameters of the chemistry education study program

\begin{tabular}{|c|c|c|c|c|c|c|c|c|c|}
\hline \multirow{2}{*}{ Class } & \multirow{2}{*}{ Mean } & Mode & Std. Deviation & \multirow{2}{*}{ Range } & \multirow{2}{*}{ Min } & \multirow{2}{*}{ Max } & \multicolumn{3}{|c|}{ Quartile } \\
\cline { 6 - 11 } & & & & & & & Q1 & Q3 \\
\hline Experiment & 2.87 & 2.82 & 0.341931 & 1.35 & 2.1 & 3.45 & 2.69 & 2.9 & 3.13 \\
\hline Control & 2.18 & $1.94^{\mathrm{a}}$ & 0.285331 & 1.48 & 1.58 & 3.06 & 1.94 & 2.21 & 2.38 \\
\hline
\end{tabular}


In general, the value of the statistical parameters in the experimental class is higher than in the control class. The average value of the experimental class (2.87) is greater than the average value of the control class (2.18). This is based on the quartile value of the experimental class greater than the quartile value in the control class. Based on these parameters, it can be concluded that the mastery of experimental class science process skills is better rather than mastery of control class science process skills.
Table 12 and Figure 4 show that the average student of the experimental class of study program chemical education has mastered the science process skills well. Indicator making data tables is the dominant indicator that is mostly controlled by students in the experimental class. While the communication indicator becomes the dominant indicator that is at least mastered by the experimental class students in the chemistry education study program.

Table 12. Distribution of mastery of science process skills indicators of chemistry education study programs for experimental class

\begin{tabular}{|c|c|c|c|c|}
\hline Basic SPS indicator & Very Not Good & No Good & Good & Very Good \\
\hline Observing & 0 & 10 & 21 & 15 \\
\hline Predicting & 5 & 13 & 17 & 19 \\
\hline Communicating & 17 & 6 & 25 & 6 \\
\hline Integrated SPS indicator & Very Not Good & No Good & Good & Very Good \\
\hline Planning an experiment & 0 & 12 & 20 & 15 \\
\hline Analyzing an experiment & 9 & 24 & 9 & 11 \\
\hline Experimenting & 2 & 16 & 15 & 15 \\
\hline Defining variables & 2 & 2 & 7 & 35 \\
\hline Creating data tables & 3 & & & 14 \\
\hline
\end{tabular}
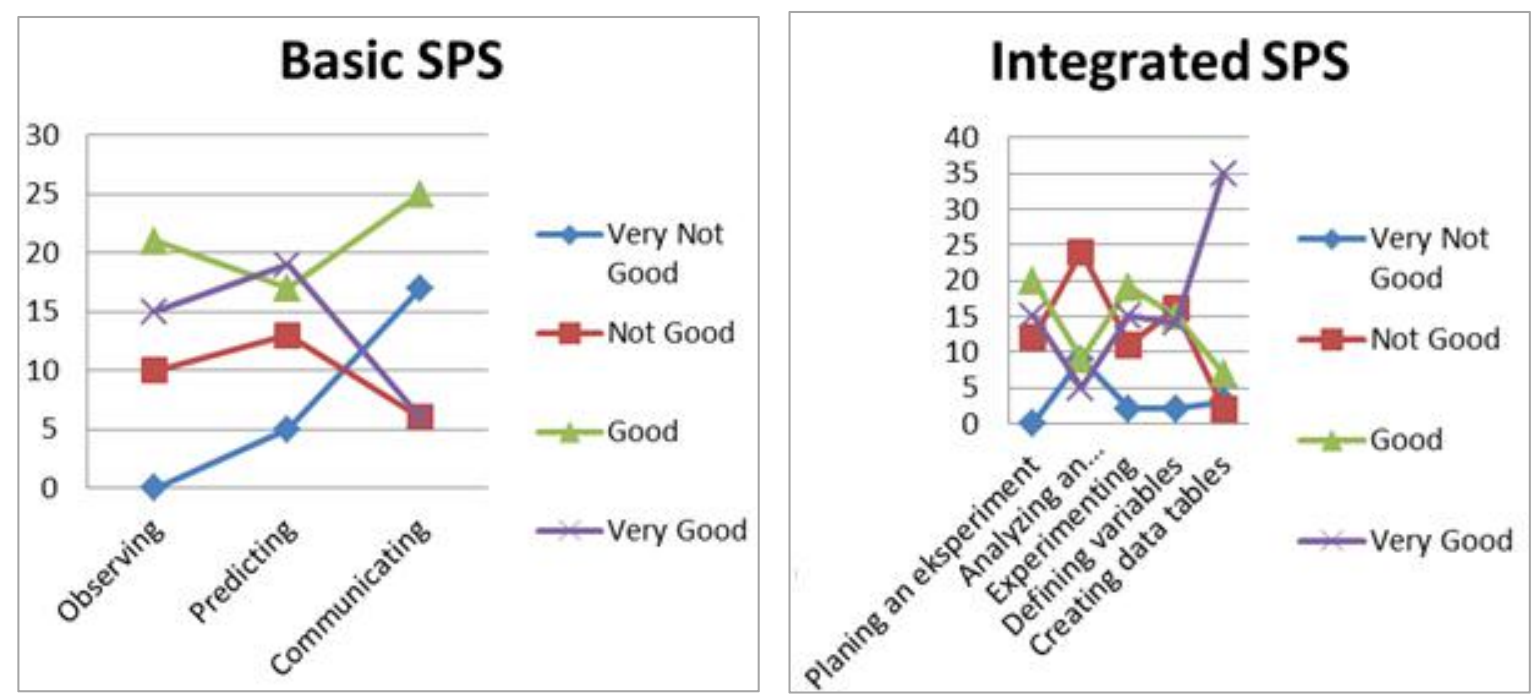

Figure 4. Distribution of SPS indicator mastery in chemistry education study programs experimental class

Table 13. Distribution of mastery indicator science process skills education courses chemistry class control

\begin{tabular}{|c|c|c|c|c|}
\hline Basic SPS indicator & Very Not Good & No Good & Good & Very Good \\
\hline Observing & 3 & 23 & 15 & 5 \\
\hline Predicting & 3 & 9 & 15 & 19 \\
\hline Communicating & 14 & 12 & 20 & 0 \\
\hline Integrated SPS indicator & Very Not Good & No Good & Good & Very Good \\
\hline Planning an experiment & 11 & 19 & 15 & 0 \\
\hline Analyzing an experiment & 30 & 24 & 16 & 0 \\
\hline Experimenting & 8 & 30 & 5 & 2 \\
\hline Defining variables & 9 & 10 & 24 & 4 \\
\hline Creating data tables & 8 & & \\
\hline
\end{tabular}



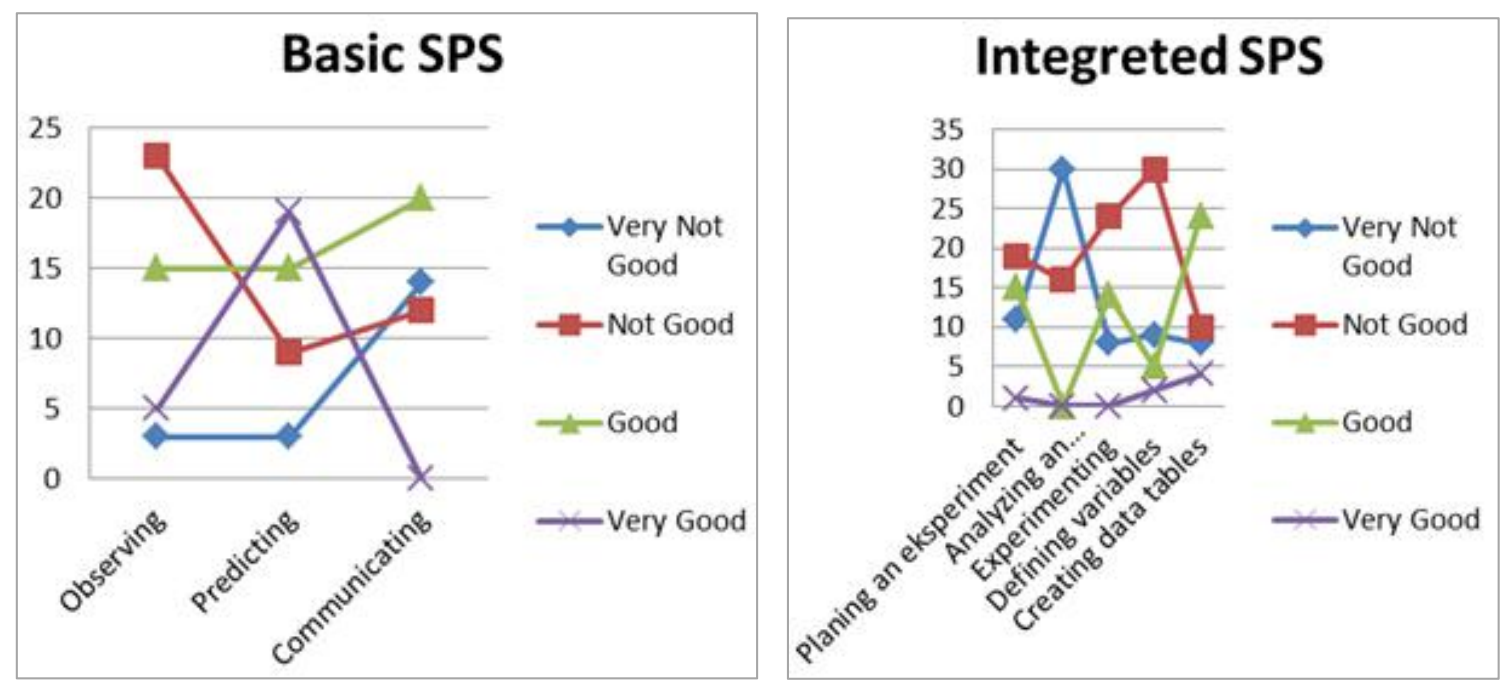

Figure 5. Distribution mastery of SPS indicators in chemistry education study programs control class

Table 13 and Figure 5 show that the average mastery of science process skill indicators in the chemistry study program control class is categorized as not good. The indicator most mastered by students is the prediction indicator. While the indicators not controlled by control class students are indicators of analyzing experiments. Based on research that has been done, it can be stated that the use of basic physics practicum guide I about practicum guidance using inquiry models can help experimental class students master science process skills well. this is consistent with the results of research conducted by [34]. Besides, this study is also in accordance with research [35] that the application of QBIM effectively enhances students' knowledge and science process skills.

Good mastery of science process skills in the experimental class because the practicum guidelines are used in accordance with the settings of the sub-chapter to develop all indicators of science process skills. Indicators of science process skills developed in this guide are observational skills, prediction, communication, plan experiments, analyze the experiment, experiment, defining variables and create a data table. In this practicum guide, it is first presented about the aims of the practicum, supporting theories, initial assignments, tools and materials, work steps, data analysis, and final assignments. Work steps contain an introduction to problems, identification of tools and materials, identification of variables, hypotheses, experimental designs, predictions, making data tables, making graphs and making a conclusion.

Presentation of problem introduction in the work steps made in the form of questions helps students to conduct experiments. As per statement [36], the questions in the guide lead students to look for answers by conducting experiments. These questions stimulate students to make hypotheses, design experiments, and experiments to prove their hypotheses. In inquiry learning before students experiment, students first create an experimental design.
Based on table 12, figure 4, it is known that in the experimental class the average student has mastered each indicator of science process skills well. The indicator of science process skills most mastered by students is an indicator of making experimental data tables. The average student is categorized very well in making data tables. Only three people who have a very bad category and 2 people who are categorized as not good at making tables. Most indicators are not mastered by students is the defining variable. This is due to a lack of practical experience, measurement errors, exams and difficulties in conducting HOPE.

Table 13 and Figure 5 show that students in the control class are still not skilled in mastering indicators of science process skills. The indicator most mastered by students is the indicator of making predictions [33]. 19 out of 46 students have predictive skills in the excellent category. During the practicum, each measurement is repeated three times. In the practicum, predictions are made after students do the first practicum. So they have made previous observations about the practicum. Based on observations, students can answer predictive questions. Conventional practicum guides are considered by students to be communicative enough to explain each procedure so that in one experiment students can deduce the relationship between each measurement variable.

The indicator which is least mastered by students is the indicator of analyzing the experiment [34]. Analyzing an experiment is a statement based on an assumption whose truth has not been proven. 30 of the 46 students in the control class were categorized as very poor in analyzing the experiment. This is because students cannot distinguish between analyzing experiments with predictions, so students make analyzing experiments that are the same as predictions [35].

During the practicum, several obstacles to achieving the success of practicum activities. Constraints experienced include: 1) the absence of pictures/illustrations in the steps 
of the experiment, so students have difficulty in designing the experiment; 2) The use of language in the experiment is less communicative steps so that students have difficulty determining steps of work to do, 3) lack of an explanation of the variables that must defining by students. Besides being influenced by the use of practical guides, students 'mastery of science process skills is also influenced by the infrastructure used, students' initial knowledge, and mastery of early science process skills for each student.

\section{Conclusions}

The results of this study indicate that there are differences in the mastery of science process skills between students who use practicum guides and inquiry models based on science process skills and students who use conventional practicum handbooks. Based on the results of hypothesis testing using a sample t-test at a significance level of 5\%, a significance value of 0.000 was obtained in the physics education study program and the chemical education study program. Where based on statistical parameters used it can be concluded that the mastery of science process skills in the experimental class is better than the mastery of science process skills in the control class.

The low mastery of science process skills is influenced by the type of practicum guidelines used. Besides, the mastery of science process skills is also influenced by the infrastructure to support practicum activities, students 'initial knowledge and mastery of students' initial science process skills.

\section{Acknowledgements}

Thank you to students of physical education and chemistry education courses that have participated in this study. Thank you also to everyone who has participated and helped in completing this research.

\section{REFERENCES}

[1] Setiawan, A., Malik, A., Suhandi, A., \& Permanasari, A. (2018). Effect of Higher Order Thinking Laboratory on the Improvement of Critical and Creative Thinking Skills. IOP Conference Series: Materials Science and Engineering 306(1).

[2] Astalini, A., Kurniawan, D. A., Perdana, R., \& Pathoni, H. (2019). Identifikasi Sikap Peserta Didik terhadap Mata Pelajaran Fisika di Sekolah Menengah Atas Negeri 5 Kota Jambi. UPEJ Unnes Physics Education Journal, 8(1), 34-43.
[3] Young, Hugh D., Freedman, Roger A., Sandin, T. R., \& Ford, A. Lewis. (2002). Fisika Universita Edisi Kesepuluh Jilid 1. Jakarta. Erlangga.

[4] Astalini, A., Kurniawan, D. A., Melsayanti, R., \& Destianti, A. (2019). SIKAP TERHADAP MATA PELAJARAN IPA DI SMP se-KABUPATEN MUARO JAMBI. Lentera Pendidikan: Jurnal Ilmu Tarbiyah dan Keguruan, 21(2), 214-227.

[5] A. Asrial, S. Syahrial, D. A. Kurniawan, M. Subandiyo, and N. Amalina. "Exploring Obstacles in Language Learning Among Prospective Primary School Teacher," International Journal of Evaluation and Research in Education (IJERE), vol. 8 no. 2, pp. 249-254, 2019.

[6] Darmaji, D., Kurniawan, D. A., \& Irdianti, I. (2019). Physics Education Students' Science Process Skills. International Journal of Evaluation and Research in Education, 8(2), 293-298.

[7] Munayyaroh, E. S. (2013). Efektivitas Pelaksanaan Asistensi Praktikum Fisika Dasar II Terhadap Sikap Sains Mahasiswa Semester Ii Program Studi Endidikan Fisika Universitas Muhammadyah Purworejo. Radiasi, pp. 116-119.

[8] Kustijono, R. (2018). The Effect of Scientific Attitudes Toward Science Process Skills in Basic Physics Practicum By Using Peer Model. International Journal of GEOMATE 15(50) 82-87.

[9] Darmaji, D., Kurniawan, D. A., Parasdila, H., \& Irdianti. 2018. "Deskripsi Keterampilan Proses Sains Mahasiswa pada Materi Termodinamika". Berkala Ilmiah Pendidikan Fisika, Vol. 6, No. 3, pp. 345-353..https://doi.org/10.20527/BIPF.V6I3.5290

[10] Dasna, R. S. K. H. I. W. (2018). Pengaruh Learning Cycle 5E terhadap Keterampilan Proses Sains Peserta Didik Kelas VIII. 3(3) 286-290.

[11] Darmaji, Kurniawan, D. A., Parasdila,H., \& Irdianti. 2018. "Description of Science Process Skills' Physics Education Students at Jambi University in Temperature and Heat Materials". Educational Review, USA, Vol. 2, No. 9, pp. 485-498. https://doi.org/10.26855/er.2018.09.005

[12] Asrial, Syahrial, D. A. Kurniawan, R. Perdana, and P. Nugroho. "Supporting Technology 4.0: Ethoconstructivist Multimedia for Elementary Schools", International Journal of Online and Biomedical Engineering (iJOE).Vol. 15 No. 14, pp. 54-66, 2019.

[13] Darmaji, Astalini, A. Rahayu, and Maison, "Darmaji, Astalini, Ani Rahayu, Maison,” EDUSAINS, vol. 10, no. 1, pp. 83-96, 2018.

[14] Darmaji, D. A. Kurniawan, and A. Suryani, "Effectiveness of Basic Physics II Practicum Guidelines Based On Science Process Skills,” J. ILMU Pendidik. Fis., vol. 4, no. 1, pp. 1-7, 2019.

[15] Rezba, R. J., Sprague, C. R., McDonnough, J. T., \& Matkins, J. J. 2007. Learning and Assessing Science Process Skills. United States of America: Kendall/Hunt Publishing Company.

[16] YILDIRIM, M., Chalik, M., \& ÖZMEN, H. (2016). A Meta-Synthesis of Turkish Studies in SPS. International 
Journal Of Environmental \& Science Education, 11 (14), 6518-6539.

[17] Asrial et al., "Identification: The effect of mathematical competence on pedagogic competence of prospective teacher," Humanit. Soc. Sci. Rev., vol. 7, no. 4, pp. 85-92, 2019.

[18] Darmaji, D. A. Kurniawan, Astalini, A. Lumbantoruan, and S. C. Samosir, "Mobile Learning in Higher Education for The Industrial Revolution 4. 0: Perception and Response of Physics Practicum," Int. J. Interact. Mob. Technol., vol. 13, no. 9, pp. 4-20, 2019.

[19] Yadav, B., \& Mishra, S. K. (2013). A Study of the impact of Laboratory Approach on Achievement and Process Skill in Scient Among is Standart Students. International Journal of Scientific and Research Publications, 3 (1), 427-432.

[20] Darmaji, D. A. Kurniawan, H. Parasdila, Irdianti, S. Hadijah, and R. Perdana, "Practicum Guide: Basic Physics-Based Of Science Process Skill," Humanit. Soc. Sci. Rev., vol. 7, no. 4, pp. 151-160, 2019.

[21] Astalini, A., Kurniawan, D. A., Kurniawan, N., \& Anggraini, L. (2019). Evaluation of Student's Attitude toward Science in Indonesia. Open Journal for Educational Research, 3(1), 1-12.

[22] S. Syahrial, A. Asrial, D. A. Kurniawan, F. Chan, A. Hariandi, R. A. Pratama, P. Nugrogo, and R. Septiasari, "The impact of etnocontructivism in social affairs on pedagogic competencies." International Journal of Evaluation and Research in Education (IJERE), vol. 8 no. 3, pp. 409-416, 2019.

[23] Darmaji, D. A. Kurniawan, H. Parasdila, and Irdianti, "Description of Science Process Skills' Physics Education Students at Jambi University in Temperature and Heat Materials," Educ. Rev., vol. 2, no. 9, pp. 485-498, 2018.

[24] Maison, Darmaji, Astalini, D. A. Kurniawan, and P. S. Indrawati, "Science process skills and motivation," Humanit. Soc. Sci. Rev., vol. 7, no. 5, pp. 48-56, 2019.

[25] Sugiyono 2018, Metode Penelitian Kombinasi (Mix Methods). Bandung: Alfabeta.

[26] Darmaji, D. A. Kurniawan, A. Suryani, and A. Lestari, “An Identification Of Physics Pre-Service Teachers ' Science Process Skills Through Science Process Skills -Based Practicum Guidebook,” J. Ilm. Pendidik. Fis. Al-BiRuNi, vol. 07, no. October, pp. 239-245, 2018.

[27] Gall, M. D., Gall, J. P., \& Borg, W. R. (2003). Educational Research An Introduction 7th Edition. USA: Pearson Education Inc.

[28] Azizah, K. N., Ibrahim, M., \& Widodo, W. (2018). Process Skill Assessment Instrument: Innovation to measure student's learning results holistically. Conf. Series: Journal of Physics: Conf. Series 947 (pp. 1-6). Boston: IOP Publishing.

[29] Wijayanto, E. (2018). Pengembangan Penuntun Praktikum Fisika Dasar 1 Materi Kesetimbangan Berbasis keterampilan Proses Sains Menggunakan Model Inkuiri. Jambi: Universitas jambi.

[30] Siregar, S. (2014). Statistik Parametrik untuk Penelitian
Kuantitatif Dilengkapi dengan Perhitungan Manual dan Aplikasi SPSS Versi 17. Jakarta: Bumi Aksara.

[31] Zeidan, A. H., \& Jayosi, M. R. (2015). SPS and Attitudes toward Science among Palestinian Secondary School Students. World Journal of Education, 13-24.

[32] S. Asrial, D. Agus Kurniawan, F. Chan, R. Septianingsih, and R. Perdana, "Multimedia innovation 4.0 in education: E-module ethnoconstructivism," Univers. J. Educ. Res., vol. 7, no. 10, pp. 2098-2107, 2019.

[33] Zulaiha, Hartono, \& Ibrahim, A. R. (2014). Pengembangan Buku Penuntun Praktikum Kimia Hidrokarbon Berbasis Keterampilan Proses Sains Di Sma. Jurnal Pendidikan Kimia, 1 (1), 87-93.

[34] Adnyana, P. B., \& Citrawathi, D. M. (2017). The Effectiveness of Question-Based Inquiry Module in Learning Biological Knowledge and SPS. International Journal Of Environmental \& Science Education, 12 (8), 1871-1878.

[35] Hirca, N. (2013). The Influence of Hands on Physics Experiments on Scientific Process Skills According to Prospective Teachers' Experiences. European Journal of Physics Education, 4 (1), 6-15.

[36] Idiege, K. J., Nja, C. O., \& Ugwu, A. N. (2017) Development of SPS among Nigerian Secondary School Science Students and Pupils: An Opinion. International Journal of Chemistry Education, 1(2), 13-21. 